\title{
A ACESSIBILIDADE LINGUÍSTICA PARA OS SURDOS NAS PROPAGANDAS ELEITORAIS TELEVISIVAS NO GOVERNO DE MATO GROSSO \\ ***
}

\section{THE LINGUISTIC ACCESSIBILITY FOR THE DEAF ON THE TELEVISIVE ELECTORAL ADVERTISEMENTS OF MATO GROSSO GOVERNMENT}

\author{
Priscila Aparecida Moraes Henkemaier Xavier ${ }^{1}$ \\ Ana Paula de Souza Pereira ${ }^{2}$ \\ Andrico Moraes Xavier ${ }^{3}$
}

Recebimento do texto: $12 / 04 / 2018$

Data de aceite: 18/05/2018

RESUMO: O presente trabalho tem como objetivo compreender o olhar discursivo do Surdo sobre os recursos acessíveis utilizados nas propagandas eleitorais de Mato Grosso nas eleições do ano de 2014. Trazemos como referencial teórico autores como, Quadros (1997), Orlandi (1999, 2003, 2005, 2010, 2011) Brandão (2004) e Strobel (2008, 2009). O processo investigativo se desenvolveu pela pesquisa qualitativa, estudo de caso, com abordagem teórica na Análise de Discurso francesa. Para a coleta de dados foram realizadas entrevistas com eleitores surdos do município de Sinop, sobre a acessibilidade nas propagandas eleitorais televisivas no ano de 2014. Por meio da análise de dados percebemos que os Surdos não tiveram acessibilidade linguística na totalidade, já que o único recurso usado foram as legendas escritas, suporte esse que não atende a maioria dos Surdos em decorrência do analfabetismo na língua portuguesa.

PALAVRAS-CHAVE: Surdo; Propaganda Eleitoral; Acessibilidade; Análise do discurso.

ABSTRACT: The present work aims at understand the deaf's view on the accessible resources used in the electoral advertisements of Mato Grosso state in the 2014 elections. We have as theoretical reference authors such as Quadros (1997), Orlandi (1999, 2003, 2005, 2010, and 2011) Brandão (2004) and Strobel $(2008,2009)$. The investigative process was developed by the qualitative research, a case study, with a theoretical approach in the French Discourse Analysis. The data was collected through interviews with deaf voters in the municipality of Sinop in Mato Grosso State of Electoral campaigns in the year 2014. Through data analysis we realized that the deaf people did not have full linguistic accessibility, since the only resource used was only the written legends, which does not serve the majority of deaf people due to illiteracy in the Portuguese language.

KEYWORDS: Deaf; Electoral Advertising; Accessibility; Discourse analysis.

\footnotetext{
${ }^{1}$ UNEMAT/SINOP. E-mail: prof.pris.1Sb@unemat-net.com

${ }^{2}$ UNEMAT/SINOP. E-mail: Souza_anitah@hotmail.com

${ }^{3}$ UNEMAT/TANGARÁ DA SERRA. E-mail: andricoxavier@unemat.br
}

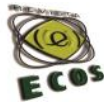




\section{INTRODUÇÃO}

Com a popularização dos meios comunicativos e a influência exercida na esfera da política atual, as campanhas eleitorais utilizam a televisão como principal meio de propaganda, visando conseguir o maior número de eleitores.

Por mais recursos tecnológicos que os candidatos usem em suas campanhas, nenhum instrumento parece ter tanta relevância quanto a utilização da linguagem, sendo esta universal. Seguindo essa reflexão, depara-se com a realidade apresentada pela mídia, quando esta mune-se da linguagem para a constituição do sujeito. Nesse sentido, ao pensarmos nos eleitores Surdos, nos questionamos como sucede a interação, já que a pessoa surda tem a língua de sinais como língua materna? A partir da indagação, entendemos que as campanhas precisam utilizar a língua de sinais em respeito e acesso ao Surdo, considerando sua identidade linguística.

Desta forma, buscamos compreender como o surdo recebe as propostas políticas, destacando como sucede a interpretação em Língua de Sinais para a compreensão do dizer, analisando a constituição do processo de cidadania no quesito específico da acessibilidade às questões políticas eleitorais para a comunidade surda.

$\mathrm{O}$ interesse pela pesquisa se deu em função da bolsa de iniciação científica com o projeto CETA e EDUTA, no qual participava. Foi a partir da participação no grupo "Edu cação científico-tecnológica e cidadania” que comecei a me interessar pelo estudo acerca da tecnologia assistiva bem como, a aprendizagem da língua de sinais.

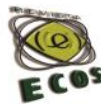


A pesquisa teve como intuito analisar como foram disponibilizadas as propagandas eleitorais televisivas do Estado de Mato Grosso no ano de 2014. Para que o processo de pesquisa se constituísse em um trabalho de relevância social, em reflexão e, desencadeamento de novas práticas para a produção das mídias eleitorais, se fez necessário uma pesquisa de campo com os eleitores surdos, a fim de verificarmos como ocorreu essa acessibilidade.

Para o processo investigativo de campo, foram utilizadas entrevistas com seis Surdos, com condições sociais diferentes, para maior qualidade de dados. Antecipadamente explicamos aos nossos entrevistados os objetivos e a relevância da pesquisa para a comunidade surda

Ademais, o discurso governamental, ao Surdo é assegurado em Lei ter sua identidade linguística preservada e o acesso as questões políticas de maneira igualitária, no entanto precisamos nos atentar que a preocupação com as pessoas com comprometimentos é um fato prematuro na história mundial, se pegarmos o histórico, certamente visualizaremos que as noções de acessibilidade começaram fortemente somente no século XX. O acesso a língua significante é um direito incontestável de qualquer ser humano, todavia a linguagem é nossa constituição e interação com o mundo exterior.

\subsection{LINGUAGUEM/ LÍNGUA}

A linguagem é o processo mais natural e inerente a constituição humana, é através dela e do pensamento lógico que nos diferenciamos dos seres irracionais. Todavia essa ciência é o principal instrumento de 
interação com o meio em que vivemos, Vygotsky (1996) discorre em suas teorias, que se não tivéssemos essa ferramenta na humanidade, não haveria uma comunicação significante. Segundo Gesueli (2006, p.280):

[...] a linguagem terá um papel fundamental, como mediadora das interações e da significação do mundo, ou ainda, a concepção de que o sujeito não significa o mundo para, a partir de então, representá-lo pela linguagem, mas, sim, que essa significação se constrói também pela própria linguagem.

Sendo assim, a linguagem é mais que um simples meio sistemático, ela se configura em uma prática social fundamental, como ressalta Orlandi (2003, p. 01) a linguagem é responsável pela “[...] mediação e transformação entre o homem e realidade em que ele vive. [...]”.

Entretanto, embasado no estudo acerca da linguagem, cabe destacar o conceito de língua. Orlandi $(2003$, p.15) apresenta que a língua "[...] é parte do trabalho social geral, constitutivo do homem e da sua história [...]”. Henge e Behenck (2008, p. 04) com base em Pêcheux explicitam que: "A noção de língua constitui a condição de possibilidade do discurso, pois é 'sobre a base dessas leis internas que se desenvolvem os processos discursivos' (Pêcheux, 1997: 91). A língua, assim, funciona como pressuposto para a análise da materialidade do discurso".

Em suma, a língua é um conjunto de sons orais (fonemas) ou gestos (Língua de Sinais), que possibilitam a comunicação dos grupos sociais. Sendo assim, a língua é uma parte da linguagem e, esta por sua vez engloba todos os processos linguísticos e significantes.

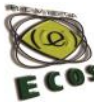




\subsection{Língua Brasileira de Sinais (LIBRAS)}

A Libras tem estruturas linguísticas influenciada pela Língua de sinais Francesa (LSF). A língua brasileira de sinais foi oficializada em 24 de abril de 2002, a partir desta data ficou decretado iminentemente que o surdo tem o direito de comunicar-se e manifestar sua cultura pela língua de sinais.

Um fato a ser destacado é a recente oficialização da Libras no Brasil, se pegarmos o histórico veremos que surgiu várias implicações acerca da LS e da educação para os Surdos, gerando assim diversas mudanças referente as pessoas Surdas, tais como: a implementação da Libras nas matrizes curriculares de cursos de licenciaturas, exame de proficiência em Libras para verificar a fluência dos intérpretes ou professores, a inclusão de alunos Surdos ou com deficiência auditiva nas escolas e universidades. Entre outras coisas supracitadas como direito básico dos Surdos no Brasil.

Após essa resolução, surgiram muitos decretos; começa-se a pensar então em políticas públicas para auxiliar na educação dos Surdos e na capacitação de professores. De acordo com Dizeu e Caporali (2005, p.588) "A língua de sinais representa um papel expressivo na vida do sujeito surdo, conduzindo-o, por intermédio de uma língua estruturada, ao desenvolvimento pleno".

Todavia, os professores e fonoaudiólogos mesmo diante da emancipação linguística, inicialmente continuavam a defender o processo de oralização como o alicerce fundamental para um ensino e comunicação efetiva do Surdo, Arcoverde (apud Dorziat 2011, p. 121) destaca que: 
O desenvolvimento da língua oral é feito através de utilização de treinamentos específicos com treinamentos exaustivos da articulação de palavras e leitura labial. Esse método de ensino designado como oralismo, tem na proibição do uso da língua de sinais uma de suas maiores características, preservando a ideia de que aos surdos cabe se oralizarem e, por meio da língua oral aprenderem. O discurso em favor ao oralismo considera como premissa a superioridade da língua oral sobre a LS, tendo na língua majoritária [oral] essas condições expostas.

Em suma, o discurso sobre a oralização com base em Quadros e Cruz (2011) foi influenciado pela longa proibição da LS desde do congresso de 1881. Enfatizamos que o educador não tinha uma didática qualitativa com alunos com comprometimentos, essa falta de capacitação/formação era primitiva nos séculos XIX e XX.

$\mathrm{Na}$ atualidade, verifica-se que mesmo com esse passado de exclusão recente, a Libras é considerada a língua materna do Surdo. Quadros e Cruz (2011, p.26) destacam que “o termo língua materna no campo linguístico (...) faz sentido, pois língua materna é aquela em que a criança se significa e significa o outro por meio de uma língua ou línguas, normalmente usada em seu contexto". Considera-se a Libras como língua materna do Surdo porque ela é apreendida de maneira natural e significante, porém muitos teóricos discordam dessa afirmação; visto que argumentam, que se um bebê Surdo nasce em uma família ouvinte estará em contato com a língua portuguesa (LP), sendo assim a LP será sua língua materna por intermédio da interação. E consequentemente, se um bebê Surdo nasce em uma família surda terá a LS como primeira língua (L1).

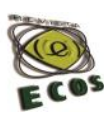


No entanto, de acordo com Quadros e Cruz, por mais que a criança Surda tenha contato com a LP e esteja com ouvintes ao seu redor, ela não reconhecerá esta língua falada, pois os aspectos semânticos e estruturais não farão sentido à ela, todavia não adquirirá de maneira natural, uma vez que o módulo interacional será auditiva/oral (comunicação oral através da voz com atribuição de significados por meio da audição).

Em contrapartida, se a criança convive com pais Surdos nativos da LS, poderá se desenvolverá melhor linguisticamente, e o módulo será visual-espacial (comunicação por meio de sinais através da visão), ou seja, aprenderá naturalmente a língua de sinais e, por conseguinte adquirará a língua Portuguesa como segunda língua (L2), já que as palavras e o contexto serão relacionadas com a L1. Dizeu e Caporali (2005, p. 588) expõe essa realidade:

[...] podemos encontrar surdos adultos que, pela falta de acesso à língua de sinais na infância, chegam à vida adulta sem ter adquirido nenhuma língua, por terem sido apenas expostos a uma língua oral e não terem desempenho satisfatório com esta. [...] Nestas condições, adquirindo a LIBRAS, ela se tornará capaz de significar o mundo [..].

\subsection{Interface: $O$ uso da televisão como instrumento de publicação do discurso político para o eleitor Surdo}

A tecnologia é um tema amplamente discutido e atualmente, não há como negar que vivemos diante de vários recursos tecnológicos que nos auxiliam e completam as atividades desenvolvidas no cotidiano. Hoje, as tecnologias de informação e comunicação (TICs), são usadas em vários 
setores, seja no armazenamento de dados, funções remotas e principalmente facilitadoras na comunicação entre as pessoas.

Cristiane Dias (2011, p.5) menciona que "o desenvolvimento tecnológico faz parte da evolução das cidades e repercute nos modos de vida do sujeito, na forma das relações sociais [...]". Dessa forma os processos tecnológicos se tornam pauta e ferramentas necessárias para a nova geração 'cibernética'.

Levando em consideração essa vasta dimensão virtual, começou-se a pensar em utilizar esses suportes como apoio para as pessoas com algum tipo de comprometimento, surgindo então, como uma nova denominação a expressão "tecnologia assistiva (TA)", que teve início em 1998 no Estados Unidos.

Segundo Santos (2013, p. 4):

[...] a TA é uma área de conhecimento que engloba recursos de baixa, média e alta tecnologia, que compreende desde uma simples bengala, instrumentos para atividades de vida diárias, orientação e mobilidade, adequação postural, adaptação de veículos, órteses e próteses, até recursos computadorizados de comunicação alternativa, acessibilidade ao computador e acessibilidade de páginas da web.

É imprescindível o uso das TAs em todos os setores, assim como o incentivo para que sejam criados novos Softwares para facilitar a vida das pessoas que necessitam desses recursos. Diante desse fato, é necessário e se faz com muita intensidade, o uso de dispositivos diferenciais, reconhecidos como interfaces, para se atingir os diferentes públicos que emergem na sociedade. 
Nesse sentido, interface, segundo o dicionário Informal 4 "é elemento que proporciona uma ligação física ou lógica entre dois sistemas ou partes de um sistema que não poderiam ser conectados diretamente" ou a "área em que coisas diversas (dois departamentos, duas ciências etc.) interagem".

Dessa maneira, a interface televisiva (canal) propagadora das campanhas eleitorais, tem o papel de levar a palavra do político para a casa do eleitor, tendo como dever, não modificar ou editar a mensagem para o receptor.

Mas ao pensarmos nesse esquema comunicativo: Interlocutormensagem- canal- receptor, nos deparamos com a seguinte indagação: Como levar o discurso do interlocutor ouvinte (político) através de um canal (meio concreto-TV) para um receptor Surdo?

A ordem do esquema deve-se atentar a um fato extremamente importante: a língua. Apesar disso para a teoria da análise do discurso, a comunicação vai além desse processo linguístico estruturalista. Pois há fatores que não estão colocados nessa representação como: a ideologia, efeitos de sentidos e condições de produção. Mostrando assim que, "a linguagem serve para comunicar e para não comunicar”. (ORLANDI 1999, p. 21)

Percebe-se então, que a televisão tem uma ação preponderante para que a mensagem seja transmitida e, sendo nosso receptor Surdo, ele precisará que a mensagem seja codificada do português para a língua de sinais. Partindo da ideia de que a língua nos constitui e constrói nossas

4 Disponível em: http://www.dicionarioinformal.com.br/interface/Acesso em: 02 de outubro de 2016. 
percepções, o Surdo necessita que esse canal seja acessível linguisticamente.

\subsection{Propagandas eleitorais: construção de interface televisiva}

Diante da enorme influência que a tecnologia exerce, os partidos políticos veem nas TICs um importante eixo de ligação com seus eleitores. Utilizando a mesma como principal aparato comunicativo por sua alta abrangência nas casas brasileiras, instaurando assim uma interface maior com a população. Para compreender isso, Alburquerque e Dias (2002, p.16) expõem que:

A eficácia comunicativa da propaganda política na televisão se explica em grande medida pelo lugar privilegiado que a televisão ocupa na vida social do país (o que leva alguns autores a caracterizá-lo como uma sociedade media-centric) e é favorecida pela ampla liberdade no uso dos recursos comunicativos da comunicação

Oliveira (2008, p.2) aponta que as campanhas eleitorais começaram a ter uma dimensão maior com o uso da TV:

[...] após o início do Horário Gratuito de Propaganda Eleitoral (HGPE), no rádio e na TV, que boa parte dos eleitores toma conhecimento dos candidatos e decidem em quem votar. O HGPE é um espaço garantido por lei para os partidos apresentarem gratuitamente as suas propagandas.

Albuquerque e Dias relatam (2002, p.15) que Horário Gratuito de Propaganda Eleitoral (HGPE) na televisão teve suas origens em 1962, mas

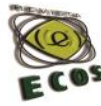


"[...] o seu impacto eleitoral foi mínimo, dado o subdesenvolvimento desse meio de comunicação. A televisão era, então, um meio fundamentalmente regional e o número de aparelhos receptores no país não atingia a marca de 2 milhões [...]". Parafraseando os teóricos citados, outro fator que impossibilitava a difusão do HGPE era o regime militar, neste período as eleições ficaram em plano secundário na política nacional atrasando o desenvolvimento.

Somente em 1989, com a eleição do presidente Collor, o uso da TV ganhou força na divulgação das propagandas eleitorais. Oliveira (2008) destaca que o candidato muniu-se com um marketing bem elaborado, recurso este, que trouxe frutos, elegendo-o.

Atualmente, “[...] as campanhas eleitorais estão cada vez mais marcadas por um alto grau de profissionalização, com propagandas políticas que atraem os eleitores por utilizarem muito bem os recursos da mídia, espaço privilegiado da disputa”. (OLIVEIRA 2008, p.3)

Em suma, HGPE possibilita ao eleitor acesso as propostas partidárias através de vídeos diários durante esse período. A propaganda no horário eleitoral ${ }^{5}$ é realizada por dois programas em bloco, com a duração de 50 minutos cada um, no $1^{\circ}$ turno, e de 20 minutos cada um, no $2^{\circ}$ turno, além de outros 30 minutos para inserções de até 60 segundos cada uma.

${ }^{5}$ Dados extraídos das cartilhas do tribunal eleitoral regional do MT.

Disponíveis em: http://www.justicaeleitoral.jus.br/arquivos/tre-mt-eleicoes-2014-cartilhade-propaganda-eleitoral-erratahttp://www.justicaeleitoral.jus.br/arquivos/tre-mt-eleicoes2014-geral-regras-da-propaganda-eleitoral-gratuita. Acesso em: 14 de julho de 2016

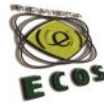


Essas exibições são realizadas de segunda a sábado por aproximadamente dois meses

Para os eleitores Surdos, os programas devem ter janela em Libras ou legendas, esses recursos são extremamente relevantes para viabilizar a acessibilidade.

\subsubsection{Legendas em Português e Janela em libras: algumas conceituações}

As legendas são mecanismos visuais que permitem o acesso as informações das programações audiovisuais. Esse recurso importante é discorrido por Araújo (2008), que destaca que antigamente os Surdos só acompanhavam as imagens sem que houvesse uma interação.

De acordo com a autora, há duas modalidades de legendas: a intralinguística para pessoas surdas e ensurdecidas (texto de partida e chegada na mesma língua) a interlinguística: para espectadores ouvintes, usada em filmes ou programas de entretenimento em língua estrangeira (texto de partida e chegada em línguas diferentes).

Segundo Araújo (2008, p.64) no Brasil usa-se:

[...] o modelo norte-americano de closed caption. Nesse sistema, as legendas são convertidas em códigos eletrônicos e inseridas na linha 21 do intervalo vertical em branco do sinal da TV, ou seja, na barra horizontal localizada entre as imagens da televisão. O telespectador acessa a legenda por meio de um decodificador localizado no controle remoto do televisor. 
Quando falamos em legendagem para Surdo, há várias delimitações que devem ser seguidas, e Araújo (2013, p.145) recomenda que o sistema de legendagem deve assumir alguns procedimentos para se tornarem mais acessíveis. Como por exemplo:

1) Informações adicionais que os ajudam a compreender o que está se passando ('passos na escada', 'um grito de terror', etc.).

2) Informações sobre quem está falando naquele momento (usar cores diferentes para facilitar).

3) A velocidade de leitura varia muito de pessoa para pessoa. O ideal seria que todos tivessem opções e pudessem escolher seu ritmo ideal. De Linde e Kay (1999) também comentam a questão da velocidade de leitura e afirmam ser difícil estabelecer uma velocidade ideal para leitores surdos. Segundo eles, há muitas variáveis que afetam a leitura tanto de ouvintes quanto de surdos/ensurdecidos, tais como o tópico do texto, o interesse do leitor, etc. Além disso, surdos e ensurdecidos são grupos diversos que apresentam diferenças no grau de surdez, na primeira língua (falada ou língua de sinais) e nas estratégias e nas habilidades de leitura.

Ressaltamos que a legenda é um recurso benéfico para o Surdo, mas é importante enfatizar que a escrita será em Língua Portuguesa, tendo em vista que a maioria dos surdos não são alfabetizados, o ideal seria a janela em Libras junto com a legenda.

\subsubsection{Janela em libras}

A janela em Libras é o recurso mais acessível para o Surdo, pois permite a ele uma "tradução" simultânea da LP para a língua de sinais. Esta 
interpretação só é possível através de um intérprete em LS, este profissional desempenha o papel de traduzir, todavia há muitos fatores que influenciam esse processo. Faria e Silva (2016, p.69) mencionam que:

Um deles refere-se ao tamanho da janela, pois se for muito pequena, não permite o entendimento das palavras digitadas ou dos sinais (observe-se que o tamanho da janela varia também conforme o tamanho do aparelho televisor). Outro motivo é o de não haver interação ou comunicação anterior entre intérpretes e organizadores dos programas, de modo que os intérpretes só têm conhecimento do conteúdo a ser interpretado no momento da interpretação. Em geral, isso resulta em traduções que fogem ao tema, bem como em perdas causadas pelo revezamento dos intérpretes.

O conhecimento prévio do intérprete é fundamental, pois ele precisa atribuir significados a palavras que possam não ter sinais. Esse fato linguístico é muito comum na maioria da interpretação. Faria e Silva (2016) enfatizam que além dessas delimitações, os responsáveis pela veiculação das propagandas devem estar atentos para variações linguísticas. A Libras também tem suas variações regionais, no qual certos sinais são diferentes de acordo com a região. "É preciso levar em conta o domínio que o receptor tem da língua em que a mensagem é transmitida, bem como as questões subjetivas e as relações linguístico-cognitivas que o sujeito-alvo da mensagem emitida é capaz de estabelecer". (Ibid, ibid p. 69)

Deste modo, é preciso pensar acerca desses recursos e, a mensagem que é transmitida e, se ela é capaz de expressar o que foi dito da maneira mais fidedigna possível, respeitando os Surdos bilíngues, oralizados e os que utilizam a comunicação total.

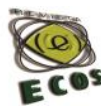




\subsection{Análise de dados: O discurso dos eleitores Surdos}

O seguinte irá descrever e interpretar os dados da pesquisa, para tanto iremos analisar as entrevistas dos eleitores Surdos, a fim de verificar como sucedeu a acessibilidade linguística nas campanhas governamentais em Mato Grosso no ano 2014.

Para iniciarmos o nosso processo investigativo foi questionado aos Surdos: Você acha que as campanhas eleitorais dos candidatos a governador do Mato Grosso deram acessibilidade ao surdo em 2014?

\begin{tabular}{|l|l|}
\hline \multicolumn{1}{|c|}{ Transcrição LIBRAS } & \multicolumn{1}{|c|}{ Tradução para o Português } \\
\hline Surdo 1: "Nenhum nada governo." & $\begin{array}{l}\text { "Não teve acessibilidade no } \\
\text { Governo." }\end{array}$ \\
\hline Surdo 2: "Não ter acessibilidade." & "Não teve acessibilidade." \\
\hline $\begin{array}{l}\text { Surdo 3: "Não nenhum eu- "Pelo menos que eu me lembre, } \\
\text { alembrar(passado) não ter nenhum. }\end{array}$ & não teve acessibilidade." \\
\hline $\begin{array}{l}\text { Surdo 4: "Ver nunca nunca sempre } \\
\text { sempre mesma coisa igual igual igual } \\
\text { até anos (passado até atual) até eu ver } \\
\text { nada." }\end{array}$ & $\begin{array}{l}\text { coisa, não mudou nada até hoje } \\
\text { essa problemática }\end{array}$ \\
\hline
\end{tabular}

Fonte: Autoria própria

As respostas dadas pelos participantes revelam que nenhum dos eleitores teve a acessibilidade discursiva nas campanhas governamentais no Mato Grosso. Visualizamos também que essa falta de acesso a propagandas 
eleitorais não é um fato atual, pois como argumenta o Surdo 4 'Nunca vi, [...] não mudou nada, até hoje essa problemática'. Refletindo acerca da resposta, verificamos que essa problemática é antiga e que permeou até as eleições de 2014.

Percebemos durante as entrevistas, as indignações dos Surdos por não terem tido o 'direito' de entender os discursos dos candidatos a governadores pela ausência acessibilidade. Como estudantes da linguagem/língua destacamos a importância da língua significante, que nesse processo "[...] ao significar nos significamos, isto é, sujeito e sentido configuram- se e é nisso que consistem os processos de identificação." (GESUELI 2006, p. 282)

Acreditamos que essa ausência de significação pode ter ficado muda, no qual o silêncio significou apenas como um descaso a essas pessoas. De acordo com Orlandi (2011, p.31) "Na perspectiva que assumimos, o silêncio não fala. O silêncio é. Ele significa. Ou melhor: no silêncio, o sentido é."

Como já citado, o intérprete é o melhor recurso para o Surdo, esse profissional é imprescindível para que haja de fato uma comunicação entre os essas pessoas e a comunidade ouvinte (vice-versa). Sendo assim, indagamos aos participantes se nas propagandas eleitorais dos governadores de Mato Grosso do ano de 2014 teve intérpretes de Libras? 


\begin{tabular}{|l|l|}
\hline \multicolumn{1}{|c|}{ Transcrição LIBRAS } & \multicolumn{1}{|c|}{ Tradução para o Português } \\
\hline $\begin{array}{l}\text { Surdo 1: "Muito difícil antigamente até } \\
\text { hoje não ter intérprete." }\end{array}$ & $\begin{array}{l}\text { "Desde as eleições passadas até a } \\
\text { atual, nunca teve intérprete." }\end{array}$ \\
\hline $\begin{array}{l}\text { Surdo 2: "Intérprete, só deputado ter } \\
\text { interprete algum tv e algum não. Governo } \\
\text { não ter." }\end{array}$ & $\begin{array}{l}\text { intérprete, os outros não tinham. } \\
\text { Mas os candidatos a governador } \\
\text { não tinham intérprete." }\end{array}$ \\
\hline $\begin{array}{l}\text { Surdo 3: "Não ter nenhum. Ver nenhum } \\
\text { não ter intérprete." }\end{array}$ & $\begin{array}{l}\text { "Não teve intérprete, eu não vi } \\
\text { nenhum." }\end{array}$ \\
\hline Surdo 4: Nunca/nunca/ nada. & "Não teve" \\
\hline
\end{tabular}

Fonte: Autoria própria

As respostas demonstraram que não tiveram intérpretes nas campanhas de 2014 e, segundo Surdo 1 'nunca teve intérprete', o Surdo 2 revela que alguns deputados disponibilizaram esses profissionais, mas que os candidatos a governadores não tinham. Dessa forma, visualizamos o quão a comunidade surda pode ter sido prejudicada pela falta de interação com o discurso político, uma vez que a TV funciona como a principal propagadora do HPGE.

Cabe mencionar, que por mais que haja o número do candidato ou as informações visuais o Surdo ficará sem a compreensão do que está sendo dito, como as propostas e reinvindicações de cada concorrente. Orlandi (2010, p.15) expõe como é relevante para o eleitor a leitura e conhecimento da política, sendo esse ato, uma ação reflexiva. 
[...]a leitura sobre eleições (...)pode levar o leitor a pensar mais demoradamente a política, sua importância na vida do cidadão, suas formas de significação na vida de cada um etc. Portanto, um acontecimento pode levar à reflexão de todo um processo de constituição da própria vida social do cidadão.

É obrigatório por lei, que os partidos políticos utilizem recursos para que as pessoas com comprometimentos possam acompanhar o andamento da política. Para a população surda, foi instaurado que as coligações devem utilizar a janela em libras ou a legenda em português.

Destacamos que a maioria escolhe disponibilizar as legendas, uma vez que se tem um custo reduzido, já que não se contrataria um proficiente em Libras. Sabendo dessa realidade, foi perguntado aos entrevistados: Você conseguiu compreender o que o candidato a governador propunha sem intérprete de Libras?

\begin{tabular}{|l|l|}
\hline \multicolumn{1}{|c|}{ Transcrição LIBRAS } & Tradução para o Português \\
\hline $\begin{array}{l}\text { Surdo 1: "Só legenda eu entender algum } \\
\text { pouco. }\end{array}$ & $\begin{array}{l}\text { "Eu entendi um pouco em } \\
\text { decorrência da legenda." }\end{array}$ \\
\hline $\begin{array}{l}\text { Surdo 2: "Não conseguir entender algum "Eu não consegui entender, pois } \\
\text { leitura-legenda não ter governo não-ter } \\
\text { janelinha." }\end{array}$ & $\begin{array}{l}\text { "Eão teve a janela com o o } \\
\text { intérprete." }\end{array}$ \\
\hline $\begin{array}{l}\text { Surdo 3: "Não ter, eu ler leitura-legenda "Não teve, eu compreendi um } \\
\text { tv mas raro conseguir entender." }\end{array}$ & $\begin{array}{l}\text { "Nouco pela legenda, mas é raro eu } \\
\text { entender o que é falado apenas } \\
\text { com a legenda." }\end{array}$ \\
\hline Surdo 4: "Não, eu não-conseguir" & "Não consegui"” \\
\hline
\end{tabular}

Fonte: Autoria própria 
Notamos que somente com as legendas os Surdos não conseguiram entender, como já falado, a maioria dos Surdos não conseguem ser alfabetizados. Em vista disso, indagamos a eles: Você entende o significado das palavras em língua portuguesa?

\begin{tabular}{|l|l|}
\hline \multicolumn{1}{|c|}{ Transcrição da LIBRAS } & \multicolumn{1}{|c|}{ Tradução para o Português } \\
\hline $\begin{array}{l}\text { Surdo 1: "Muito difícil entender } \\
\text { porque palavra significado difícil } \\
\text { entender palavra não conhecer palavra } \\
\text { só algum palavra simples conhecer." }\end{array}$ & $\begin{array}{l}\text { "Muito difícil compreender o } \\
\text { significado das palavras em } \\
\text { português, eu entendo somente } \\
\text { algumas palavras simples." }\end{array}$ \\
\hline $\begin{array}{l}\text { Surdo 2: "Eu entender pouco porque } \\
\text { legenda português diferente própria } \\
\text { língua de sinais e língua portuguesa, eu } \\
\text { entender pouco." }\end{array}$ & $\begin{array}{l}\text { "Entendo pouco a legenda de } \\
\text { própria língua de sinais." }\end{array}$ \\
\hline $\begin{array}{l}\text { Surdo 3: "Sim e algum não, exemplo diferente da } \\
\text { palavra não conhecer e algum palavra } \\
\text { simples sim significado." }\end{array}$ & $\begin{array}{l}\text { "Não entendo muito, porque tem } \\
\text { palavras que eu conheço o o } \\
\text { significado, mas tem outras que eu } \\
\text { não sei." }\end{array}$ \\
\hline $\begin{array}{l}\text { Surdo 4: "Muito português legenda eu } \\
\text { difícil palavra só saber-eu palavra/ } \\
\text { palavra/ palavra simples." }\end{array}$ & $\begin{array}{l}\text { "Eu não sei o significado de } \\
\text { muitas palavras, não entendo } \\
\text { muito o português, só sei palavras } \\
\text { simples. Muito difícil legenda." }\end{array}$ \\
\hline
\end{tabular}

Fonte: Autoria própria

Como averiguamos, os Surdos participantes da nossa pesquisa, não entendem a Língua portuguesa, percebemos o analfabetismo funcional presente em nossos entrevistados, que por vezes não conseguem assimilar o significado das palavras em português. Os Surdos 2 e 3 são acadêmicos de pedagogia e agronomia e, mesmo estando nesse patamar de instrução mencionam que não compreendem totalmente a escrita em LP.

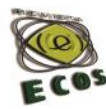


Diante desse fato, compreendemos que as legendas são insuficientes para essas pessoas, é claro que há Surdos que entendem, porém são minoria. Deste modo, a legenda torna-se apenas um objeto obrigatório sendo inútil para a maioria das pessoas, que possuem a Libras como a língua significante. Ou seja, de nada servirá a escrita se não houver significância, “[...] não é uma questão de tudo ou nada, é uma questão de natureza, de condições, de modo de relação, de trabalho, de produção de sentidos, em uma palavra: de historicidade." (ORLANDI 1999, p.9)

Além do não entendimento das legendas, a reprodução e a cor das legendas são ruins. 90\% dos entrevistados, disseram que elas são pequenas e, tem a reprodução rápida demais para que o Surdo possa tentar decodificar.

Ao contrário do que se pensa, os surdos têm maior dificuldade de leitura na língua oral de seu país, porque esta funciona como segunda língua para eles, sendo a língua de sinais sua primeira língua. Essa visão bilíngue vem sendo absorvida vagarosamente, [...] Na verdade, os surdos brasileiros ainda aprendem o português como língua materna, apresentando, por essa razão, baixa proficiência no idioma, principalmente no que diz respeito à leitura e escrita. (ARAÚJO, 2008, p.63).

Temos assim mais de uma problemática, o primeiro seria o analfabetismo em decorrência da falta de escolas bilíngues que ensinem para as crianças surdas a Língua Portuguesa de maneira efetiva. "A tarefa de ensino da língua portuguesa tornar-se-á possível, se o processo for de alfabetização de segunda língua, sendo a língua de sinais reconhecida e efetivamente a primeira língua." (QUADROS 1997, p.23). 
O segundo problema é o modo como a legenda é exposta em vídeo, talvez o que falte seja um monitoramento durante as exibições televisivas. O ideal seria a presença de intérpretes de Libras durante as exibições, mas, conforme é exposto na pesquisa, não houve a presença desses profissionais, o que pode ter prejudicado o acesso dos discursos para os eleitores Surdos.

Quando perguntados se conseguiram entender as propostas políticas por meio das propagandas, eles responderam que:

\begin{tabular}{|l|l|}
\hline \multicolumn{1}{|c|}{ Transcrição da LIBRAS } & Tradução para o Português \\
\hline $\begin{array}{l}\text { Surdo 1: não conseguir entender } \\
\text { proposta governo cada. }\end{array}$ & $\begin{array}{l}\text { "Não consegui entender as } \\
\text { propostas." }\end{array}$ \\
\hline $\begin{array}{l}\text { Surdo 2: até agora nada conseguir } \\
\text { entender nada proposta mas só algum fala } \\
\text { "saúde, educação e outro" }\end{array}$ & $\begin{array}{l}\text { entender quase nada, só vi } \\
\text { algumas propostas sobre saúde, } \\
\text { educação e outros." }\end{array}$ \\
\hline $\begin{array}{l}\text { Surdo 3: algum explicar não-conseguir } \\
\text { entender proposta governo. eu procurar } \\
\text { pesquisar site governo explicar esclarece } \\
\text { porque internet eu entender esclarecer. }\end{array}$ & $\begin{array}{l}\text { "Alguns partes de explicação das } \\
\text { consigo entender pesquisei no site } \\
\text { do candidato à governo, para } \\
\text { poder entender melhor, porque } \\
\text { internet me ajuda esclarecer." }\end{array}$ \\
\hline $\begin{array}{l}\text { Surdo 4: não, eu não-saber proposta } \\
\text { nunca. não-saber como governo explicar } \\
\text { nada eu entender. outra explicar divulgar } \\
\text { para ouvintes bem e eu surdo falta } \\
\text { intérprete ficar esclarecer mas não- } \\
\text { conseguir entender sem interprete. }\end{array}$ & $\begin{array}{l}\text { entendi/entendo o que o governo } \\
\text { explica. } \\
\text { chegam para os ouvintes, para } \\
\text { mim, surdo nada se esclarece, não } \\
\text { entendo." }\end{array}$ \\
\hline
\end{tabular}

Fonte: Autoria própria

As respostas demonstram que os Surdos não conseguiram entender a fala dos candidatos. Esmiuçando mais, percebemos que somente duas pessoas tiveram acesso de maneira reduzida, o Surdo 3 destaca que 
"pesquisei no site do candidato a governo, para poder entender melhor, porque internet me ajuda esclarecer." E o Surdo 2 expõe "consegui entender quase nada, só vi algumas propostas sobre saúde, educação e outros."

Destacamos que ambos compreenderam as informações, pois supõese que por estarem na universidade dispõem de maior facilidade com a internet em comparação com o surdo 4 e 1 que possuem o ensino fundamental incompleto, deste modo as condições de produção fundamentam as suas respostas e conhecimento. Orlandi (2003, p. 30) explica que as condições de produção "[...] é o contexto imediato. E se consideramos em sentidos amplo, as condições de produção incluem o contexto sócio histórico e ideológico."

O que comprovamos com a análise das entrevistas, é que nenhum dos candidatos utilizou a janela em libras, eles optaram pela legenda em português. Ressaltamos que a nação brasileira tem aproximadamente 5,4 milhões de cidadões surdos, ou seja, um número expressivo de pessoas com esse o compromentimento auditivo.

Dessa maneira, visualisamos que em todas as respostas os eleitores Surdos se sentem descontentes com a falta de recursos para acompanhar o HGPE, as palavras como 'Nada', 'não entendi', 'nunca', 'não ter', emergem das sinalizações de maneira abrupta e sob forma de indignação. Gesueli (2006, p.290) destaca que "O surdo tem, até hoje, vivido um movimento de resistência, buscando o reconhecimento de sua cultura, tentando fazer-se presente como minoria linguística, mesmo que ainda fragmentado e dividido pelo grupo que se submete à hegemonia cultural."

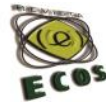


É claro, que a legenda supri um pouco das necessidades de alguns, apesar disso, para a maioria é apenas mais um enfeite em uma interface, que apesar de inovadora e tecnológica é ineficaz para $85 \%$ dos Surdos, que acabam ficando em um 'silêncio' absoluto, tendo a mensagem interrompida por não conseguirem decodificar e entender. Araújo (2013, p. 143) elucida que em relação à leitura de legendas:

[...] os surdos estão em desvantagem se comparados aos ouvintes por diversas razões. Os ouvintes têm o input gramatical durante a leitura e a compreensão. Conseguem, por terem a língua portuguesa como língua materna, preencher com mais facilidade as lacunas deixadas durante a leitura por não conseguirem acompanhar totalmente a velocidade da legenda.

Sendo assim, a problemática aqui exemplificada se torna um empencilho para o eleitor Surdo, que a cada eleição se vê excluído de exercer de forma plena esse processo democrático, o que propaga a eles é a indiferença dos canditados, pois destacam que: "Não teve acessibilidade no Governo". (Surdo 1) e que “[...] Essas informações chegam para os ouvintes, para mim, surdo nada se esclarece, não entendo". (Surdo

Os candidatos por sua vez, seguem o que está delimitado na Lei que os oportunizam em escolher qual o recurso irão utilizar, porém enfatizamos que é de suma importância que os candidatos conheçam a comunidade surda. Pois “[...]Falar sobre os processos de interações comunicativas, sobre a língua de sinais e sobre a língua portuguesa escrita são formas de desenvolver a conscientização do valor das línguas e suas respectivas complexidades". (QUADROS, 1997, p. 31) Ou seja, o conhecimento 
dessas pessoas é relevante para haja um consenso sobre qual suporte esse público alvo necessita.

\section{CONSIDERAÇÕES FINAIS}

A partir do estudo bibliográfico e da análise dos dados, concluímos que não houve acessibilidade de maneira satisfatória para os Surdos nas eleições governamentais no Estado do Mato Grosso em 2014. Percebemos que há muito o que discutir quando falamos em acessibilidade linguística. A exibição somente da legenda deixou a desejar, uma vez que não foi assimilada pelos eleitores entrevistados.

A legenda se configura como um suporte acessível apenas para os Surdos alfabetizados, como exposto, essa não é a realidade da maioria dos Surdos. Mais do que pensar apenas nos recursos, deve-se (re) pensar no ensino para o Surdo, buscando a criação de escolas bilíngues. A inclusão do Surdo nas escolas sem essa educação a partir da língua de sinais perpetua a exclusão. O que gera uma não aprendizagem da LP para essas pessoas.

Dessa forma, a janela em Libras é a melhor opção, para que haja realmente uma acessibilidade, no entanto é difícil visualizar as coligações que optam por esse recurso, na pesquisa apresentada, os três candidatos a governador(a) não utilizaram esse instrumento. Atualmente, com o desenvolvimento da tecnologia assistiva, se faz necessário refletir como deve ser exibida a janela em Libras, tendo vista que o espaço dado é pequeno. O que muito teóricos propõem é a divisão igualitária da tela entre o interlocutor e o intérprete. 
Esperamos que a partir dos resultados da pesquisa, o governo se atente para a criação de leis que monitorem o andamento desses recursos, ademais percebemos nos discursos dos Surdos, que eles querem de fato como recurso principal a janela em Libras.

Contudo, podemos concluir que o mais importante é o respeito a língua de sinais e, a oferta da mesma em todos os setores da sociedade, visto que a Libras é a segunda língua oficial do Brasil, sendo assim não disponibilizá-la de maneira efetiva para o Surdo, principalmente nos pronunciamentos oficiais e políticos se configura como um retrocesso, onde o significado de 'minoria' se torna de fato, exclusão linguística.

\section{Referências}

ABNT. Acessibilidade em comunicação na televisão. Accessibility in TV captions. Norma Brasileira ABNT NBR 15290:2005.

ABUQUERQue, Dias. Afonso, Maria. Propaganda Política e a Construção da Imagem Partidária no Brasil: considerações preliminares civitas - Revista de Ciências Sociais v.2, nº 2, dez. 2002.

ACOVERDE, Rossana Delmar de Lima, Dos desencontros com a linguagem escrita a um encontro Plurilinguístico in DORZIAT, Ana (ORG) ESTUDOS SURDOS: diferentes olhares. Porto Alegre: Mediação, 2011.

ARAÚJO, Vera L. S. Por um modelo de legendagem para Surdos no brasil. Tradução e Comunicação - Revista Brasileira de Tradutores • Nº 17, Ano 2009. 
Legendagem de campanhas políticas e de propagandas de anúncios publicitários televisivos brasileiros: uma pesquisa de recepção. Horizontes de Linguística Aplicada, ano 12, n. 1, 2013. BRANDÃO, Helena, H. Nagamine. Introdução à Análise do Discurso, Campinas, SP: Editora da Unicamp, Ed. 2004.

Brasil. Lei $\mathbf{n}^{\mathbf{0}}$ 4.737, de 15 de julho de 1965. Disponível em:http://www.planalto.gov.br/ccivil_03/leis/L4737.htm. Acesso em: 20 de Abril de 2016.

Portaria 310, de 27 de junho de 2006 do Ministério das Comunicações. Disponível em: http://www.mc.gov.br/portarias/24680portaria-n-310-de-27-de-junho-de-2006. Acesso em: 20 de Abril de 2016. Resolução no 23.191, de 16 de dezembro de 2009. Disponível em: ://www.tse.jus.br/legislacao-tse/res/2009/RES231912009.htm. Acesso em: 20 de Abril de 2016.

A Lei $\mathbf{n}^{0}$ 13.146, de 2015. Disponível em: http://www.planalto.gov.br/ccivil_03/_Ato2015-

2018/2015/Lei/L13146.htm._Acesso em: 20 de Abril de 2016.

- Lei $\mathrm{n}^{0} 4.304$ de 07 de abril de 2004. Disponível em: http://alerjln1.alerj.rj.gov.br/contLei.nsf/f25edae7e64db53b032564fe0052 62ef/77217ebe8ec8e17e83256e66004e6cc5?OpenDocument. Acesso em: 20 de Abril de 2016.

DIAS, Cristiane. O ensino, A leitura e a escrita: sobre conectividade e mobilidade. Campinas, 2011. Entremeios: revista de estudos do discurso. v.9, jul/2011. 
FARIA e SILVA, Núbia, Daniel. Legendas e janelas: questão de acessibilidade. Revista Sinalizar, v.1, n.1, p. 65-77, jan./jun 2016.

GESUELI, M. Z. Lingua(gem) e identidade: a surdez em questão. Educ. Soc., Campinas, v. 27, n. 94, p. 277-292, jan./abr. 2006.

ORLANDI, Eni Pulcinelli. Discurso e Leitura. $4^{\mathrm{a}}$ ed. São Paulo, Cortez; Campinas, SP: Editora da Universidade Estadual de Campinas, 1999. (Coleção passando a limpo).

Análise de Discurso: princípios e procedimentos. Campinas: Pontes, 2003

. Discurso e Texto: formulação e circulação de sentidos. Campinas: Pontes, 2005.

Formas de conhecimento, informação e políticas públicas. Animus - revista interamericana de comunicação midiática. Mestrado em Comunicação - UFSM v.17, jan-junho 2010.

As formas do silêncio: no movimento dos sentidos. 3. ed. Campinas: Ed. Unicamp, 2011.

OLIVEIRA, Luiz. A Propaganda Política no Brasil e as suas peculiaridades: um olhar sobre a interface entre comunicação e política de Afonso Albuquerque. Encontro nacional: UFRGS: 2008.

PERLIN, G. Histórias de vida surda: identidades em questão [tese]. Porto Alegre (RS): Universidade Federal do Rio Grande do Sul, 2005. PERLIN Gladis e MIRANDA WILSON. Surdos: o narrar e a política. In: Estudos Surdos - Ponto de Vista: Revista de Educação e Processos Inclusivos nº 5, UFSC/ NUP/CED, Florianópolis, 2003 
QUADROS, Ronice Müller. Educação de surdos: a aquisição da

linguagem. Porto Alegre: Artemed, 1997.

QUADROS, Ronice, e PERLIN, Gladis. Ouvinte: o outro do ser surdo In:

QUADROS, Ronice (org.) Estudos surdos I- Petrópolis, RJ: Arara Azul, 2007.

. e CRUZ, C. R. Língua de sinais: instrumentos de avaliação.

Porto Alegre: Artmed, 2011.

SANTOS. Danielle Aparecida do Nascimento. Tecnologia Assistiva, Acessibilidade e Formação de Professores: perspectivas de Inclusão Escolar. Anais do evento/CD - ISSN 2175-8778 V.II/UNEMAT, 2013.

SKLIAR, Carlos (org.) A Surdez: um olhar sobre a diferença. Mediação. Porto Alegre: 1998.

STROBEL, K. As imagens do outro sobre a cultura surda.

Florianópolis: UFSC, 2008.

. História da educação de surdos. Universidade Federal de Santa

Catarina. Florianópolis, 2009.

VYGOTSKY, L. S. Pensamento e Linguagem. Rio de Janeiro: Martins Fontes, 1996. 